\title{
Conservation and analysis of the physicochemical parameters of a Congo food plant alicamentary [Pteridium aquilinum (L.) Kuhn]
}

\author{
Arnaud W.G. Tamba Sompila ${ }^{1,2,3^{*}}$, J. E. Moussounga ${ }^{1,2,3}$, A.B. Madiélé Mabika ${ }^{1,6}$, \\ N.P.G Pambou-Tobi ${ }^{1,2,3}$, P. Diakabana ${ }^{1,4,5}$, B.D.E. Miakayizila ${ }^{3}$, \\ M. Dzondo-Gadet ${ }^{1,2,3,4}$ and T. Silou ${ }^{4,5}$
}

${ }^{1}$ Centre de Recherche et d'Initiation des Projets de Technologie, cité scientifique, route de l'auberge de Gascogne, Brazzaville, $R$. Congo

${ }^{2}$ Laboratoire de Bioprocédés alimentaires et médicaux, ENSP-UMNG, BP. 69 Brazzaville, R. Congo

${ }^{3}$ Ecole Nationale Supérieure Polytechnique, Université Marien NGOUABI, Brazzaville

${ }^{4}$ EPRAN-Congo, Pôle d'Excellence en Alimentation et Nutrition, Faculté des Sciences et Techniques, Université Marien NGOUABI, Brazzaville

${ }^{5}$ Ecole Supérieure de Technologie des Cataractes, Brazzaville

${ }^{6}$ Unité de Chimie du Végétal et de la Vie, FST-UMNG, BP. 69 Brazzaville, R. Congo

*Corresponding author

\section{A B S T R A C T}

\section{Keywords \\ Conservation, Analysis, Physicochemical parameters, Food plant, Pteridium} aquilinum

\section{Article Info}

Accepted:

15 August 2019 Available Online:

10 September 2019

\begin{abstract}
In order to contribute to the valorization of non-timber products from the Congo, the aim of the study was to contribute to the nutritional value of $P$. aquilinum fern. The harvested fern plants were previously dried by solar drying for up to 4 hours and finally crushed to obtain a powder after sieving. This powder made it possible to study the biochemical and physicochemical characteristics of fronds. The results of the biochemical analysis revealed moisture contents of $13.87 \pm 0.17 \%$; the ash content of $9.25 \pm 0.49 \%$; lipid content $7.07 \pm$ $0.41 \%$, and that of soluble sugars $0.54 \pm 0.021$. Meanwhile, the protein and total carbohydrate contents are relatively high, respectively $20.33 \pm 0.58 \%$ and $49.51 \pm 0.2 \%$. The physicochemical analysis, based on the measurement of the chemical indices, showed that only the peroxide index complies with the STAN 210-1999 Codex standards. In addition, the other two indices do not comply with the standards of the CODEX STAN 210-1999 standard, i.e., $256.25 \mathrm{mg}$ of $\mathrm{KOH} / \mathrm{g}$ of saponification oil, $14.03 \pm 1.5 \%$ of oleic acid for the acid number and the peroxide value $8.6 \pm 1.75 \mathrm{meq} \mathrm{O}_{2} / \mathrm{kg}$ of oil.
\end{abstract}

\section{Introduction}

Looking back, we find that man lived in harmony with his environment. He knew how to take advantage of the great wealth of fauna and flora to obtain a balanced diet, with regard to proteins, vitamins and mineral salts (Mbemba and Remacle, 1992). 
In developing countries, undernutrition and child malnutrition are major problems often recorded in public health.

In addition, Congo has a significant diversity of food tree species that are sometimes poorly exploited. Many of these species contribute significantly to the equilibrium of rural food rations. Indeed, various edible parts of the plants are used directly or after transformation. These include asparagus, matembele (leaves of Hypomea batatas), and ferns. Taking into account the ferns, in the Congo, we have a number that are almost completely edible, including the bracken fern.

In certain localities of the Congo, this bracken fern is called in vernacular language by makoungou or fesi; The bracken fern is known under the scientific name: $P$. aquilinum (L) Kunh is a fern belonging to the family Dennstaedtiaceae. There are two subspecies identified to date, which are aquilinum and caudatum (Thomson, 2000).

Fern is a crop of young processed fronds that are used as human food in some parts of the world, although there are reports of its toxic effects on livestock (Fenwick GR, 2006, Yamada K, et al., 2007, Madeja, J, et al., 2009).

In traditional medicine, its analgesic, antibacterial and antiparasitic properties have been reported (Hassan SW, et al., 2007, Swain $\mathrm{T}, 1974)$. In addition, its decoction is orally taken as a remedy for malarial fever disturbances (Nwiloh Barine Innocent et al., 2014).

The purpose of this study is to value while keeping the bracken fern considered as a vegetable, but unfortunately little known to the Congolese population by making a nutritional contribution.

\section{Materials and Methods}

\section{Plant material}

The young fronds of the fern were used as vegetable raw material (Figure 1).

\section{Drying equipment}

A boat-type solar dryer designed at CRIPT was used to dry the young fronds of $P$. aquilinum with the following characteristics:

$6.0 \mathrm{~m}$ long, $1.60 \mathrm{~m}$ wide and $1.05 \mathrm{~m}$ high, with a sheet absorber arranged over a length of $2 \mathrm{~m}$ and a width of $1.60 \mathrm{~m}$ in the form of a $0.60 \mathrm{~m}^{2}$ surface partition on the roof of the dryer. It has a wide aeration zone of $0.4 \mathrm{~m}$ and at least $1.60 \mathrm{~m}$ long located at the end of the surface of the catchment area.

This dryer has a capacity of more than $10 \mathrm{~kg}$ of products to dry (Figure 2).

\section{Methods}

\section{Collection and identification of plant material}

The whole plant of $P$. aquilinum was harvested in the department of Brazzaville precisely in the northern districts of Brazzaville. But only young fresh fronds were used. The harvest took place in August 2017 and this plant was identified at the level of the national herbarium at the Institute of Research in Exact and Natural Science (IRSEN).

\section{Sample preparation and drying kinetics}

After separating the young fronds from the rest of the plant (the rhizome), they were washed with tap water to rid them of certain impurities. Once washed, they are drained to remove as much water as possible before being placed in the solar dryer. 
The young fronds are arranged in the dryer in order to facilitate the almost total elimination of the water. These fronds were dried for 4 hours following a kinetic while noting the variations of drying temperature and humidity of the air in the dryer.

When the samples are completely dry, they are first milled using an electric grinder (Bruders type B1-133), and then a fine powder is obtained after sieving.

\section{Drying kinetics}

The drying kinetics made it possible to carry out weighing every $30 \mathrm{~min}$, at the same time measurements of the temperature and that of the humidity of the air in the dryer during drying. The brand Thermo-anemometer Lafayette A-M-Flex was used as a device to collect the temperature and humidity of the air in the dryer.

This kinetics made it possible to determine the dry basis water contents and the rate of drying of the sample by the following formulas:

$$
\begin{aligned}
& X=\frac{\boldsymbol{m}-\boldsymbol{M} \boldsymbol{S}}{\boldsymbol{M} \boldsymbol{S}} \\
& -\frac{\boldsymbol{d X}}{\boldsymbol{d} \boldsymbol{t}}=\frac{-[\boldsymbol{X}(\boldsymbol{t}+\Delta \boldsymbol{t})-X(\boldsymbol{t})]}{\Delta t}
\end{aligned}
$$

\section{Chemical and biochemical analysis}

\section{Chemical composition}

The chemical composition of the fine powder of $P$. aquilinum was evaluated in terms of protein, water (moisture), ash, soluble carbohydrate, total fat and lipid contents.

\section{Crude protein content}

Proteins were determined by the common method of (Glowa, 1974) using microKjeldahl;

\section{Moisture content}

The water content was determined according to the (official) AOAC method, 1997 where two (2) grams of powder were placed in the oven at $103 \pm 2^{\circ} \mathrm{C}$ for 24 hours. The measurement is stopped until the dry residue is of constant weight;

\section{Ash content}

The amount of ash has also been determined by standard methods (Pomeraz and Meloan, 1994). $2 \mathrm{~g}$ of the dry matter were weighed into the porcelain crucibles which were placed in the muffle furnace at a temperature of $550^{\circ} \mathrm{C}$ for 8 hours until a white residue of constant weight was obtained;

\section{Soluble carbohydrates}

Soluble carbohydrates were determined by the method of (Yemme, 1954).

\section{Total carbohydrates}

The total carbohydrates were obtained by simple difference according to the following formula (Manzi et al., 2004):

Carbohydrates $=100-$ [lipids + proteins + water + Ash] (3)

\section{Lipid extraction}

$15 \mathrm{~g}$ of $P$. aquilinum was used to extract the oil using $100 \mathrm{ml}$ of $\mathrm{n}$-hexane in a soxhlet extractor (Moulinex SeBPREP'LINE model $850)$ at $60^{\circ} \mathrm{C}$ for $6 \mathrm{~h}$, as described in the standard method ( AOAC, 1997). The solvent was evaporated at $500^{\circ} \mathrm{C}$ under reduced pressure using a rotary evaporator $(\mathrm{N}-1$ model, Eyela, Tokyo Rikakikal Co., Ltd. Japan).

The oil was recovered, placed in a flask and placed under nitrogen until complete removal of the solvent. 


\section{Analysis of physicochemical indices}

The chemical analysis of the oil was evaluated by measuring the chemical indices. These indices were determined according to known standard methods: The acid number according to standard method 969.1 (AOAC, 2012); the saponification number according to the standard method 965.33 (AOAC, 12) and the peroxide content according to the standard method 920.160 (AOAC, 2012).

\section{Evaluation of the oil indices of $P$. aquilinum}

The indices of oils are usually determined according to the standard methods: the acid number [AOAC (12), the standard method 969.1], the iodine content [AOAC (12), standard method 993.20), and the saponification value [AOAC Standard Method 965.33 (12)] and peroxide content [AOAC Standard Method 920.160 (12)].

\section{Statistical analysis of the data}

All experiments, measurements and analyses were performed three times, and the results presented are the average values of three replicates. Curves and coefficients of determination (R2) were obtained using the Microsoft Excel 2010 software. Significance was defined at $\mathrm{P}<0.05$.

\section{Results and Discussion}

\section{Drying kinetics}

The result on the kinetics of drying is shown in Figure 3, which shows the loss of mass, the temperature inside the dryer and that of the relative humidity as a function of time.

Most food products contain high amounts of water, which is partially or completely removed during dehydration. Drying food matrices involves both internal and external processes of heat and mass transfer.
The kinetics of drying achieved, resulted in the plots of the curves appearing on the plot presented above. Figure 3 shows the variation curves of product mass, temperature and air humidity in the dryer as a function of time.

The temperature curve shows an evolution that exponentially increases until reaching its maximum peak at $41.7^{\circ} \mathrm{C}$ after $210 \mathrm{~min}$ in the dryer.

As shown in Figure 3, the mass of the sample decreases significantly with increasing drying temperature. The curve of the mass can be described in 3 phases: an initial phase of 0 to 60 min where one observes a sudden and fast fall of mass (28.17 to $23.09 \mathrm{~g})$. This significant loss may be due to the removal of water on the surface of the product. Several researchers have reported similar work in different food matrices (Ridene et al., 2006; Arlabosse, 2008). An intermediate phase between 90 and $270 \mathrm{~min}$ where there is a gradual and extensive decrease in mass. A third phase where a very slow and progressive mass loss is observed until stabilization after $360 \mathrm{~min}$.

The curve of the relative humidity as a function of time shows a progressive decreasing pace, until stabilizing from 180 min. This curve is the reverse of the temperature curve (Figure 3a).

Figure 3a shows the dry basis water content or the amount of water evaporated as a function of time. This curve confirms that of mass loss. There was a rapid loss of water during the first 90 minutes. Between 90 and $270 \mathrm{~min}$, there is a slow loss of water that evolves gradually and tends to stabilize just after $270 \mathrm{~min}$.

Subsequently, we evaluated the rate of drying of the product by the formula (2) that we presented previously. This is determined in terms of time. 
The drying speed is given in Figure $3 \mathrm{~b}$ below.

The drying rate of $P$. aquilinum powder samples were evaluated by calculation according to formula 2. This speed is determined in terms of time.

Figure 4 shows the curve of variation of the drying speed. The latter is the speed of the air inside the dryer which depends on the speed of the ambient air outside the dryer. The speed curve shown in Figure 4, corresponds to the speed of water loss of the product inside the dryer. It can be seen that the initial value of the speed is very low, especially since there is no renewed air circulation. This low speed justifies the way of circulation or convection of air which is done naturally. The rate of water loss gradually decreases to around 210$240 \mathrm{~min}$.

\section{Chemical composition}

The chemical composition of $P$. aquilinum powder is summarized in Table 1. This shows that the powder contains approximately $7.07 \pm$ $0.41 \%$ oil content, $9.25 \pm 0.49 \%$ ash content and $13.87 \pm 0.17 \%$ ash content. water content. It is also noted that the total protein and carbohydrate levels of the slings are relatively high $(20.33 \pm 0.58 \%$ and $58.89 \pm 0.2 \%$ respectively).

Soluble carbohydrates determined gave $0.54 \pm$ $0.021 \%$. This low soluble sugar content reveals that the fern fronds contain very little reducing sugars and that the other sugars are involved in the saccharide bonds.

We were led to verify all the sugars in this plant by performing a calculation formula 3 .

Awe, S and Amobi, O., (2015) also studied the chemical composition of $P$. aquilinum fronds. Their work reports a slightly high protein content $(21.90 \%)$, while the ash, water and lipid contents are relatively lower than those obtained in our work. This can be explained by the source of $P$. aquilinum fronds where geographical factors may have an influence.

Table.1 Biochemical composition of fronds of $P$. aquilinum

\begin{tabular}{|l|c|}
\hline Composition & Young fronds of $\boldsymbol{P}$. aquilinum $\mathbf{( \% )}$ \\
\hline Moisture & $13.87 \pm 0.17$ \\
\hline Ash & $9.25 \pm 0.49$ \\
\hline Lipid & $7.07 \pm 0.41$ \\
\hline Proteins $\left(\mathbf{N}_{\mathbf{t}} \mathbf{6 6 . 2 5}\right)$ & $20.33 \pm 0.58$ \\
\hline Carbohydrates & $58.89 \pm 0.2$ \\
\hline Carbohydrates Soluble & $0.54 \pm 0.021$ \\
\hline
\end{tabular}

Table.2 Oil index of different seeds

\begin{tabular}{|l|c|}
\hline Indices & Young fronds of $\boldsymbol{P}$. aquilinum (\%) \\
\hline Peroxide Values (Pv) & $8.6 \pm 0.75$ \\
\hline Acidity (Oleic) & $14.03 \pm 1.5$ \\
\hline Saponification Values (Sv) & $256.25 \pm 6.2$ \\
\hline
\end{tabular}




\section{Figure.1}

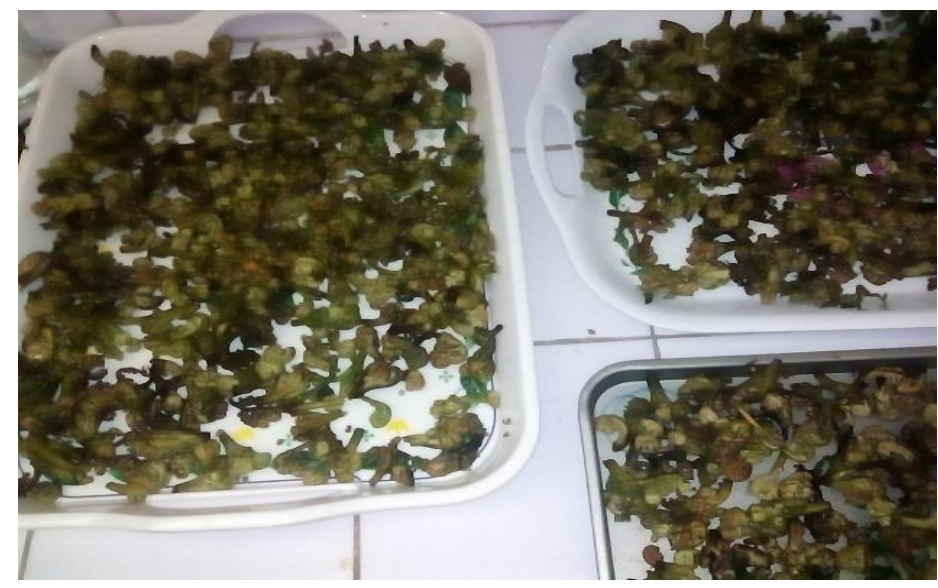

Figure.2

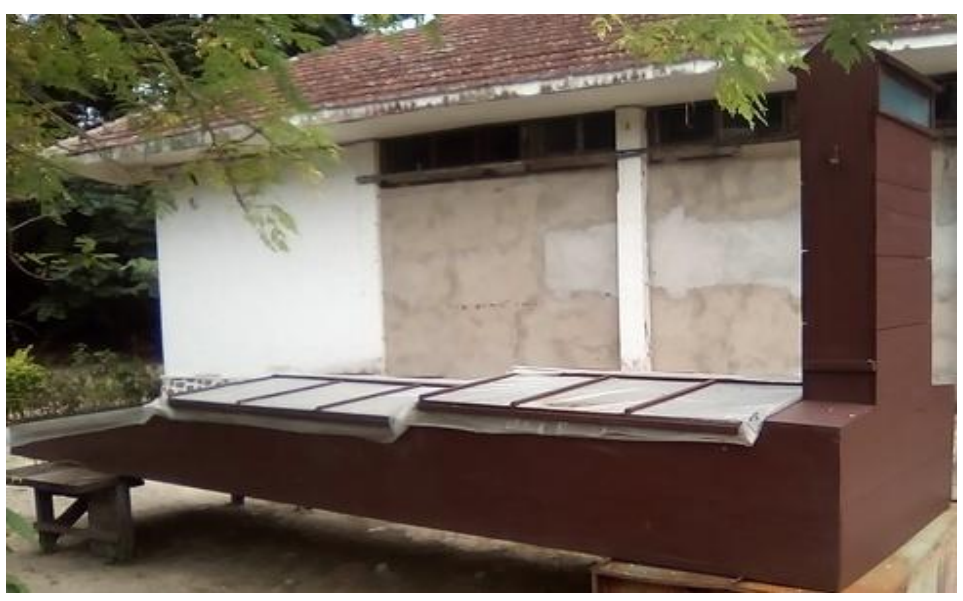

Figure.3

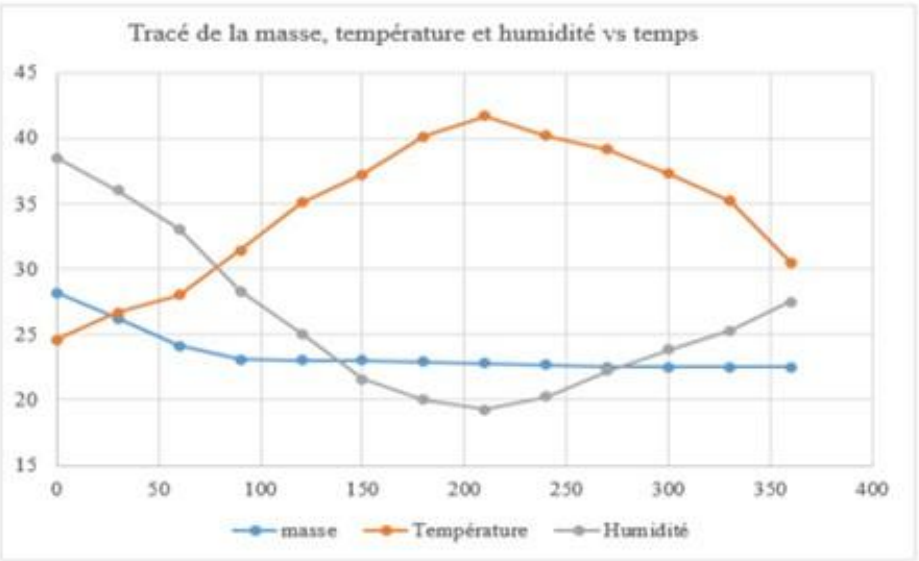




\section{Figure.3a}

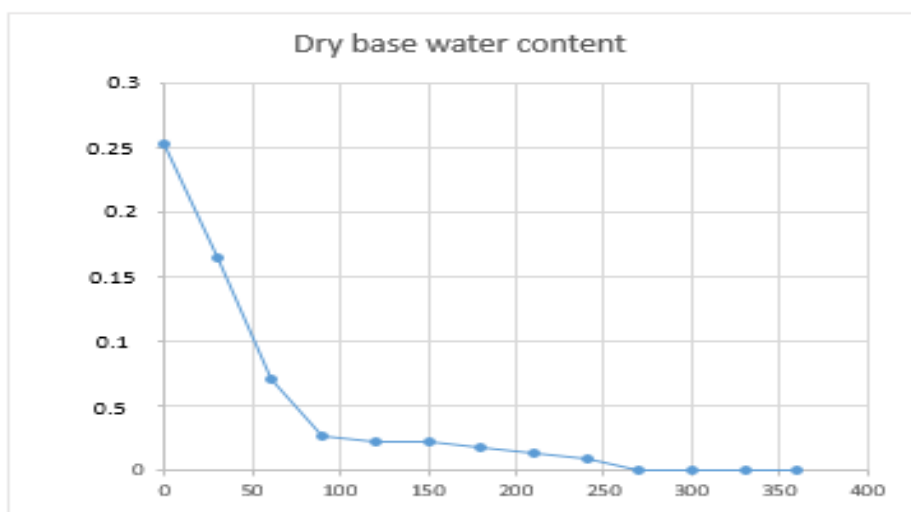

Figure.3b

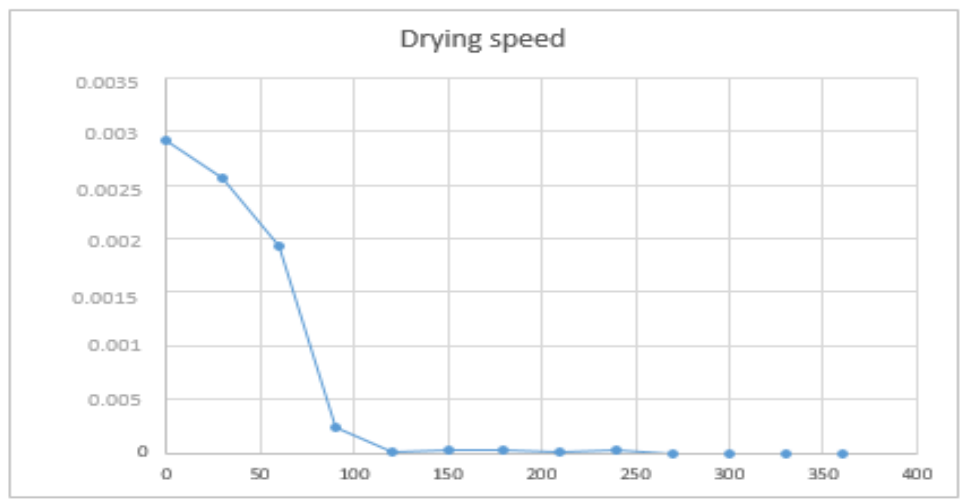

Figure.4

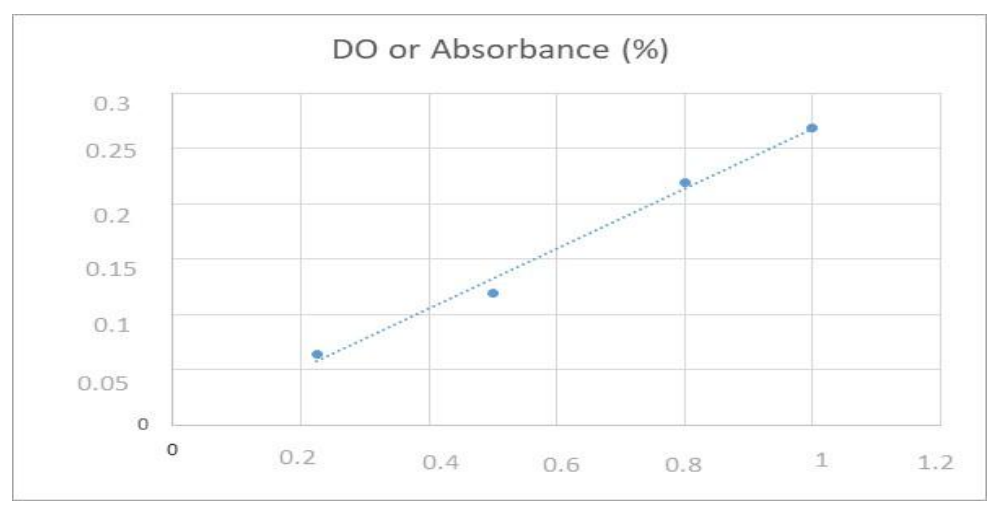

\section{Physico-chemical indices}

The acid number (Ia), the peroxide content (Ip) and the value of the saponification number (Is) are shown in Table 2.
In agreement with the literature, the acid number can be considered as an indicator of hydrolytic deterioration (Yaghmur et al., 2001) of fat caused by a combination of 
enzymes and moisture (Gan et al., 2005 ) but it can also be related to their quality.

When the acid value content of the oil exceeds the objectionable quantity, it must be discarded (AB Bhattacharya et al., 2008) because a high acidity is not acceptable in any consumable and commercial product due to the bad taste caused by the degradation products (volatile and non-volatile compounds) of free fatty acids (Yaghmur et al., 2001) during a treatment. The standards of CODEX STAN 210-1999, stipulate for unconventional oils, values of acid number is $4.0 \mathrm{mg} \mathrm{KOH} / \mathrm{g}$ of oil. In this study, the acid value of $P$. aquilinum (Ia) oil obtained is $14.03 \pm 1.5$. This value reveals a high acidity of the oil studied, which excludes it for a human diet.

According to Bensmira et al., 2007, peroxide formation is an important concern from the point of view of rancidity and toxicology, and are also considered to be good guides to oil quality (H.L. Gan et al., 2005). For this reason, some authors report that the extent of oil oxidation is frequently assessed by measuring peroxide levels (Melton et al., 1994, Yaghmur et al., 2001). The results obtained from the peroxide index (Ip) give the average value of $8.6 \pm 1.75$ meq $\mathrm{O}_{2} / \mathrm{kg}$ of oil. In fact, the value obtained is higher than the limit value recommended for a food oil by CODEX STAN 210-1999 which is 15 meq O $/ \mathrm{kg}$ of oil. The value of this index indicates that the oil of $P$. aquilinum fronds studied does not oxidize easily, as it must probably be rich in saturated fatty acids. At room temperature, this oil is solid.

As regards the saponification number, the value of $256.25 \mathrm{mg} \mathrm{KOH} \mathrm{/} \mathrm{g}$ of oil does not comply with CODEX STAN 210-1999 standards, the standard of which is between 189.7 and $195.2 \mathrm{mg} \mathrm{KOH} \mathrm{/} \mathrm{100g} \mathrm{d} \mathrm{'oil.} \mathrm{This}$ oil can be used in cosmetics or soap.
Regarding soluble sugars, the respective concentrations found in solutions S1, S2, S3 are: $0.56 \mathrm{mg} / \mathrm{ml}, 0.52 \mathrm{mg} / \mathrm{ml}, 0.54 \mathrm{mg} / \mathrm{ml}$. Taking into account the dilution factor and the concentrations obtained was possible to calculate the carbohydrate masses. These masses were used to determine the percentages of soluble carbohydrates, which gave an average value of $0.54 \% \pm 0.021$ (Table 1).

In conclusion, the fronds of $P$. aquilinum have a good nutritional value according to the chemical composition determined. The protein content $(20.33 \pm 0.58 \%)$ is very important that this vegetable deserves to be consumed and valorized in terms of the toxicity that can be eliminated by cooking. The ash content $(9.25 \pm 0.49 \%)$ reveals that the fronds of the fern contain a certain amount of minerals. The oil of $P$. aquilinum is solid at room temperature. It is dark green in color.

The fronds of $P$. aquilinum contain a low content of soluble sugars $(0.54 \pm 0.02 \%)$. The total carbohydrates $(49.48 \pm 0.2 \%)$ contained in $P$. aquilinum fronds make this vegetable a good source of protein and energy.

\section{References}

Atanu B. Bhattacharya, M. G. Sajilata, Sudha R. Tiwari, Rekha S. Singhal, 2008. Regeneration of thermally polymerized frying oils with adsorbents, Food Chemistry 110, 562-570

AOAC, 1997. Official methods and recommended pratics of the American Oil Chemists Society (5th ed.). Champaign, USA: AOCS Press.

Awe, S and Amobi, O.O, 2015. Antibacterial, Phytochemical and Proximate Analysis of Pteridium aquilinum, International Journal of Research in Pharmacy and Biosciences, (2), pp 1-7.

A. Yaghmur, A. Aserin, Y. Mizrahi, A. Nerd 
and N. Garti, 2001. Evaluation of Argan Oil for Deep-Fat Frying; Lebensm.Wiss. u.-Technol., 34, 124 - 130

Codex Alimentarius, 1999. Codex Alimentarius standards for fats and oils from vegetable sources 2. Codex Alimentarius standards for named vegetable oil. Codex Alimentarius Stan 210.

Fenwick. G. R, 2006. Bracken (Pteridium aquilinum) toxic effects and toxic constituents. J. sci. food. Agric. 6: 147173.

Glowa. W, 1974. Zircomuim dioxide, a new catalyst in the KJELDAHL method for total $\mathrm{N}$ determination. J. Assoc. Anal. Chem., 57, 1228-1230.

Hassan. S. W, Umar R. A, Dabai Yu, Ebbo A. A, Faruk U. Z, 2007. Antibacterial, phytochemical and Toxicity studies of Pteridium aquilinum L. (Dennestaedtiaceae) in rabbits. $J$. Pharmacol. Toxicol. 2: 168-175

Gan, H. L., Y. B. Che Man, C. P. Tan, I. NorAini, S. A. H. Nazimah, 2005. Characterisation of vegetable oils by surface acoustic wave sensing electronic nose. Food Chemistry 89, 507-518

Madeja. J, Harmata. K, Kolaczek. P, Karprinska-Kolaczek. M, Platek. K, Naks, P, 2009. Bracken (Pteridium aquilinum L. Kuhn), Mistletoe (Viscum album L.), and bladdernut (Staphylea pinnata L.). Mysterious plants with unusual applications. Cultural and ethnobotanical studies. Plants and culture: seeds of the cultural; heritage of Europe. Edipulgia. www.edipulgia.it.

Melton. S. L, Jafar. S, Sykes. D and Trigiano, M. K, 1994. Review of stability measurements for frying oils and fried food flavor. Journal of the American Oil Chemists 1 Society, 71, $1301-1308$

Meriem Bensmira , Bo Jiang, Consolate Nsabimana, Tang Jian, 2007. Eff ect of
Lavender and Thyme incorporation in sunflower seed oil on its resistance to frying temperatures, Food Research International 40, 341-346

Mbemba. F et Remacle. J, 1992, Inventaire et composition chimique des aliments et denrées alimentaires traditionnels du Kwango-Kwilu au Zaïre. Presses universitaires de Namur, Namur, p : 80.

Nwiloh Barine Innocent, Uwakwe Augustine, Monago Comfort, 2014. In vivo antimalarial activity of methanolic extract of young fronds of Pteridium aquilinum L. kuhn in mice infected with Plasmodium berghei. Journal of pharmacology Online, vol.1, 114-120.

Pearson. D, 1976. General Methods in the Chemical Analysis of Food London. Longman Group Ltd. London, pp: 6-26.

Pieroni. A, Quave C. L, 2005. Traditional pharmacopoeias and medicines among Albanians and Italians in Southern Italy:a comparison. J. Ethnopharmacol 101:258 - 270 .

Pomeraz. Y and C. Meloan, 1994. Food Analysis: Theory and Practice. 3rd Edn., Chapman and Hall, New York, pp: 778.

Swain. T, 1974. Biochemical evolution in plants. In comprehensive Biochemistry, 29 part A, comparative biochemistry, Molecular evolution, Florkin M, Stotz EH (Eds). Elsevier, Amsterdam.

Thomson J.A, 2000. Morphological and genomic diversity in the genus Pteridium (Dennstaedtiaceae). Annals of Botany, vol. 85, pp. 77-99.

Yamada. K, Ojika. M, Kigoshi. H, 2007. Ptaquiloside, the major toxin of bracken, and related terpene glycosides: chemistry, biology and ecology. Nat. prod. Rep., 24:798 -813.

Yemm. E. W, Willis. A. J, 1954. The estimation of carbohydrates in plant extracts by anthrone. Biochem.J. 57, 508-514. 
Manzi. P, Marconi. S, Aguzzi. A and L. Pizzoferrato, 2004. Commercial mushrooms: nutritional quality and effect of cooking. Food Chemistry, 84: 201-206.

Ridene. H, Azzouz. S, Ghorbel. D, 2006. Séchage des tomates par l'air chaud :
Cinétique et qualité.1er Séminaire Maghrébin sur les Sciences et Technologies de séchage. Arlabosse, P. 2008. Séchage industriel. Aspects pratiques. Techniques de l'Ingénieur, J. 2455:1-24.

\section{How to cite this article:}

Arnaud, W.G. Tamba Sompila, J.E. Moussounga, A.B. Madiélé Mabika, N.P.G. PambouTobil, P. Diakabana, B.D.E. Miakayizila, M. Dzondo-Gadet and Silou, T. 2019. Conservation and Analysis of the Physicochemical Parameters of a Congo Food Plant Alicamentary [Pteridium aquilinum (L.) Kuhn]. Int.J.Curr.Microbiol.App.Sci. 8(09): 247-256. doi: https://doi.org/10.20546/ijcmas.2019.809.030 